\title{
WOMEN EMPOWERMENT IN THE ECONOMIC DEVELOPMENT OF NAGA CITY
}

\author{
Emelita O. Menes \\ Nueva Caceres University, Philippines
}

\begin{abstract}
Penelitian deskriptif-evaluatif ini melihat sejauh mana kontribusi perempuan pengusaha dalam pembangunan ekonomi di Naga City. Kemampuan dalam hal planning, organizing, capability building, financial management dan monitoring menjadi tolok ukur pemberdayaan dalam operasi bisnis yang mereka lakukan. Hasil temuan menunjukkan bahwa pencapaian tujuan bisnis dipengaruhi oleh kepribadian dan kebijakan operasional yang mereka lakukan. Tugas yang sulit bagi mereka adalah membuat kegiatan dan anggaran yang terinci. Ada perbedaan antusiasme dan sikap inovasi dari pengusaha perempuan dari area non komersial dan area komersial. Pengusaha di daerah komersial merasa lebih yakin bahwa mereka akan bertahan di kompetisi yang ketat sehingga membuat mereka kurang peduli dengan aspek manajemen bisnis yang berbeda. Wanita mengalami kesulitan dalam menyesuaikan diri dengan lingkunganyang terus kerubah karena perubahan membawa konwensi pada perubahan biaya, tenaga kerja dan menggeser produk untuk memenuhi tuntutan perubahan.
\end{abstract}

Keywords: woman empowerment, economic, development,

\section{INTRODUCTION}

In all African societies, Women have been looked upon as lower forms of creatures. Our tradition favors men against Women. Women are not seen as individuals who have their own mind. For many years, Women have assumed one imposed role after another- slave, sex object for relaxation at will, bearer of children, cook and servant of the family.

In Nigeria, women were supposed to pursue their feminine roles of child-bearing and home making. Even after Nigeria attained independence it did not change the negative perception of women. Women were not considered capable of handling any administrative post. They should stay at home while their men think for them. The struggle for the empowerment of Women did not start in recent times. It has for the past centuries been in existence.
Although neo-colonialists and those who believe in the white man's superiority have attributed the origin of Women liberation movement to the USA claiming that the movement was gingered by the American Civil Rights Movement which was emulated by other countries particularly the third world countries, It is however pertinent to note that the move for the empowerment of Women had its foothold and impulse in the primary societies taking into cognizance the relentless efforts of Deborah who directed a war against the Canaanites the enemies of God. And the Israelites and came out victoriously.

For the majority of women, continuing obstacles have hindered their ability to achieve economic autonomy and to ensure sustainable livelihoods for themselves and their dependants. 
Women are active in a variety of economic areas, which they often combine, ranging from wage labor and subsistence farming and fishing, to the informal sector. However, legal and customary barriers to ownership of or means of access to land, natural resources, capital, credit, technology and other means of production, as well as wage differentials, contribute to impeding the economic progress of women.

The Women's Empowerment Principles are a set of Principles for business offering guidance on how to empower women in the workplace, marketplace and community. They are the result of collaboration between the United Nations Development Fund for Women (UNIFEM, part of UN Women) and the United Nations Global Compact.

Thedevelopment of the Principles included an international multi-stakeholder consultation process, which was launched in March 2009. Sub-titled Equality Means Business, the Principles emphasize the business case for corporate action to promote gender equality and women's empowerment and are informed by real-life business practices and input gathered from across the globe. Rather than being prescriptive or a new initiative to which business is asked to subscribe, the Women's Empowerment Principles seek to point the way to best practice by elaborating the gender dimension of good corporate citizenship, the UN Global Compact, and business' role in sustainable development. As well as being a useful guide for business, it is hoped that Principles will inform other stakeholders, including governments, in their engagement with business.

In line with the nation's promotion of women's empowerment, gender equality, women's human rights and gender responsive development as embodied in various laws and policies, Gender and Development (GAD) has been integrated in the different departments of Local Government Unit of Naga City, down to the barangay level, to ensure the fundamental equality before the law of men and women.

Since 2003, by virtue of City Ordinance No. 2003-045, otherwise known as Women Development Code of Naga City, GAD has been integrated in planning and budgeting system through the formulation of GAD plans and disbursing funds for the purpose. Efforts have been exerted by all concerned to provide the appropriate services for the continuous development of women through variety of programs, projects and activities that promote gender responsive governance, protect and fulfill a women's human rights, and promote women's economic empowerment. This study evaluated the extent of contribution of women entrepreneurs in the economic development in the selected Barangay in Naga City, C/Y 20122013. More specifically, this study answered the following questions:

1. What is the profile of women entrepreneurs in Naga City?

2. What is the level of effectiveness of the women entrepreneurs along business planning, organizing, capability building, and financial management and monitoring?

3. What are the risk management skills of the women entrepreneurs in terms of handling several business portfolio, business expansion and loans management?

4. Is there significant relationship between the level of effectiveness and their risk management skills?

5. Are there significant differences in the level of effectiveness of women entrepreneurs in business management among aspects and areas?

\section{THEORETICAL FRAMEWORK}

The extent of contribution of women in the economic development of Naga City, is anchored on principles of women behavior in the management of business. 
Crawford (2012) stated that Millennium Development Goals_Gender empowerment is one particular goal which we still need to heavily work on, considering that many developing countries and patriarchal societies have yet to break free from the shackles of gender stereotyping. Gender empowerment may even be one of the most crucial keys towards achieving the rest of the other goals like poverty, hunger, and health.

Although there have been numerous efforts in achieving gender empowerment and equality in development countries, it's safe to say that more often than not, many such initiatives wither before they can actually take root. These snuffs out the sparks of hope that many disadvantaged women rely on to break free from the vicious cycle of violence and poverty. Yet despite the fact there have been many failed programs and failed attempts for women, there are also success stories worthy of drawing inspiration from one such example is that of women in Naga City in the Bicol Region of the Philippines.

According to a report in the Phil GAD (2009) Portal of the National Commission of the Role of Filipino Women entitled "Women Empowerment and Development: the Experience of Naga City," laws and ordinances geared towards promoting women's empowerment and gender equality, partnerships between the public and private sectors, and budget commitments are essential elements in ensuring that initiatives for women are both institutionalized and sustainable.

The Women Development Code of Naga City can be considered a great step in the city's efforts to actualize the potentials of many women. The code doesn't only identify key gender issues like low participation of women in the economic sector, domestic violence, commoditization, and the like, but it points out key solutions in targeting many of these issues thereby allowing more women to break the glass the ceiling.

The code empowers many women NGOs by ensuring that women as a disadvantaged sector are well represented in many of the government's standing committees. Apart from that, the budget for gender empowerment has also been increased to ensure that the programs and services for women are made more sustainable in the long run. Summits for women have also been held in order to ensure that emerging issues are identified and addressed.

The code has also paved the way for a more gender sensitive framework in the education curricula. Naga City's efforts are inspiring in that despite the challenge posed by limited resources, initiatives continue to be made in order to solve existing problems on gender. If Naga City was able to pull it off, there is no reason why other cities in developing nations can't. This is the perfect example of thinking globally and yet acting locally.

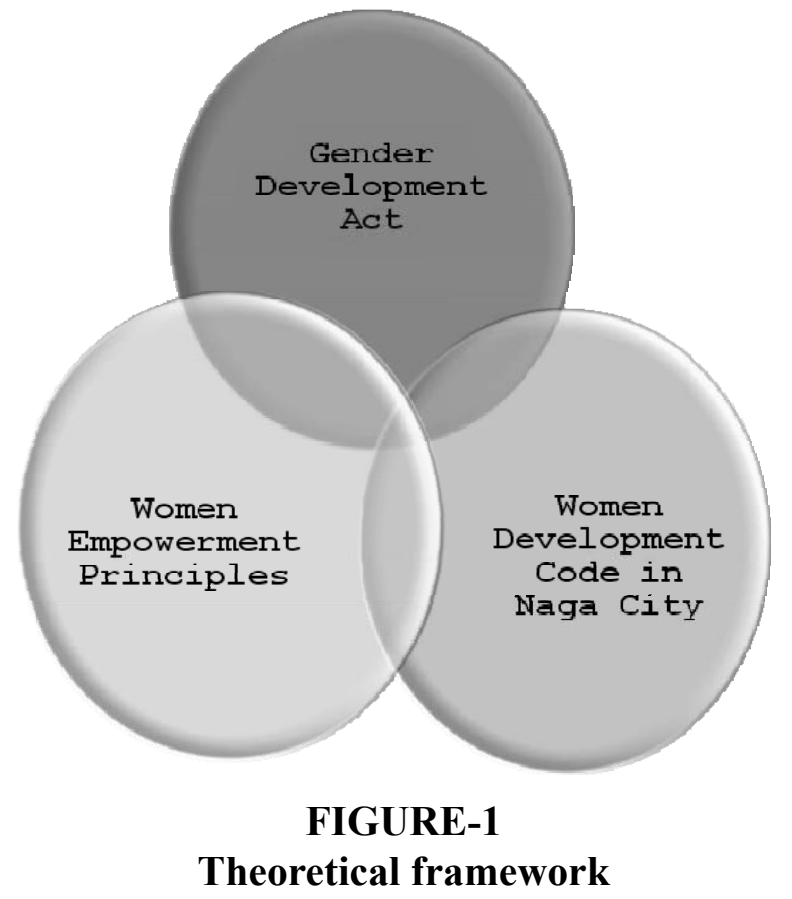

Crawford (2012) states that the Women's Empowerment Principles are a set of Principles for business offering guidance on how to empower women in the workplace, marketplace and community. They are the result of collaboration between the United Nations Development Fund 
for Women (UNIFEM, part of UN Women) and the United Nations Global Compact. The development of the Principles included an international multi stakeholder consultation process, which was launched in March 2009.

Sub-titled Equality Means Business, the Principles emphasize the business case for corporate action to promote gender equality and women's empowerment and are informed by real-life business practices and input gathered from across the globe. Rather than being prescriptive or a new initiative to which business is asked to subscribe, the Women's Empowerment Principles seek to point the way to best practice by elaborating the gender dimension of good corporate citizenship, the UN Global Compact, and business' role in sustainable development. As well as being a useful guide for business, it is hoped that Principles will inform other stakeholders, including governments, in their engagement with business.

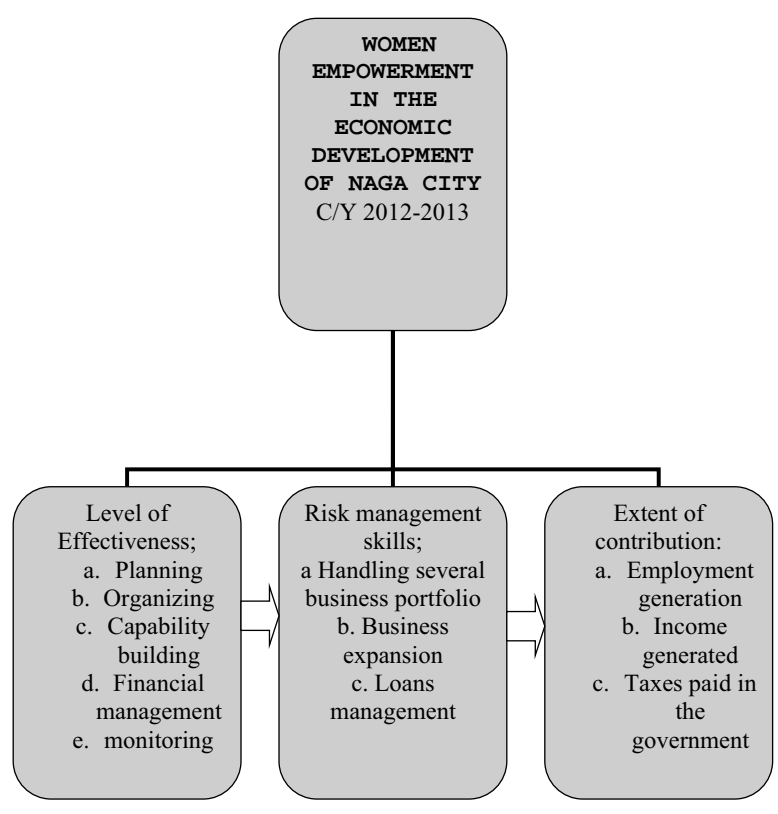

\section{RESULTS AND DISCUSSION Profile of Respondents}

The results shows that age range of women entrepreneur was 18 to more than 50 years of age. Thirty percent of the women entrepreneurs are 43 to 50 years old and $60.51 \%$ were 25 to 42 years old. Above 51 years old, there were only $12(2.80 \%)$ women entrepreneurs.

Almost $62 \%(61.86 \%)$ of the respondents were married and $31.78 \%$ single. There were college graduates (80.37), and of these $44.86 \%$ in their postgraduate programs. Only $17 \%$ were high school graduates. As to religion, 91.12\% were Roman Catholics.

Income range of the women entrepreneurs was P5,000-P10,000 (54.44\%) and only 7\% were earning above P15,000. Seventy three per cent however considered their household income to be medium. This was contradictory to the income figures. As to lifestyle, $72.79 \%$ indicated that they have average lifestyle.

Personal profile of the women entrepreneurs showed that they were middle-aged ( 31 to 50 years old). This is supported by the data on educational attainment where majority were college graduates. Considering however their income, it can be noted that approximately $72 \%$ are in the income bracket of 5000 to 15,000 . Considering their married marital status and their family, these income figures can be indicative of them living below the poverty threshold level of P15,000.

\section{Business Profile of the Women Entrepreneurs}

Sixty five per cent $(65.42 \%)$ indicated that their initial capital investment ranged from P10,000 to P50,000. Sixteen per cent however, have initial capitalization of more than P100,000. Business type of the majority $(90.42 \%)$ was sole proprietorship and $28.04 \%$ were in the marketing business. Only $11.68 \%$ are running professional service organizations. These business establishments have 1-5 manpower resources when they started and now $41.35 \%$ have more than six employees. It is worth considering also that there was an increase in the number of businesses with 1 to 5 employees at present. 
This could mean that there was a reduction in the number of employees from the initial to the present operation.

More than majorities (58.64\%) have been in their business for 1-5 years already and $18.22 \%$, more than 10 years and for those who have been in the business for more than 15 years already, $14.72 \%$. Sixty one per cent, $(61.45 \%)$ of the businesswomen rent their space and primarily their business was on merchandise (55.61\%). Only $18.69 \%$ were into the raw materials business. Their operation ran from Monday to Sunday $(64.02 \%)$. Income derived from their businesses is below P100, 000.00 (72.43\%)

\section{Management Effectiveness of Women Entrepreneurs}

The capabilities and effectiveness of the women entrepreneurs along planning, organizing, capability building, financial management and monitoring were assessed to provide indicative trend on their degree of empowerment in operating their businesses.

Planning. From the result of the eight (8) parameters included in the planning process, it can be noted that the women entrepreneurs define their goals in the determination of priorities (4.25). Rank 2, with a mean rating of 4.18, was setting personal policies and the marketing policies (4.17). The lowest rating was given to making the plans operational through detailed activities and budgeting.

Findings have shown that the attainment of the goals of the businesses of the women entrepreneurs is guided by their personal as well as the operational policies. What appeared as a more difficult task for them was detailed planning of activities and the accompanying budget for each detailed activity. This involves assistance already from other personnel for this entails already more detailed technical and financial considerations.

Organizing. Among the parameters, the highest rating (4.36) for the determination of the specific activities needed to achieve based on a defined goals and objectives. Rank 2, with a mean rating of 4.26 , were assignment of activities to specific persons or units and maintaining continuity of operations with the least break of disruption. The lowest rating (2.77) was on the clarification of roles and functions in a changing environment. Data seem to suggest that the women entrepreneurs are aware and knowledgeable of what they are doing in relation to what they would want to attain. Women entrepreneurs see to it that what are planned are properly carried over through the organization of its people and the giving of corresponding responsibilities to them. The lower rating on the clarification of roles could be explained by the nature of the environment that we have. Women find difficulty in adjusting to the ever changing environment outside of their sphere. Coping up with the changing times is quite difficult for if one aspect will be tinkered, everything will be changed. This means a change in cost, manpower and shifting products to meet the changing demands. This is one reason why there is a need for diversification or developing other product forms to meet the demands of the market.

Directing. Directing according to the women entrepreneurs is on the division of work among the members (4.26). It also means oneness or unity in management for a more synergistic action (4.20) and valuing of interest for a common good (4.18). If unity in management is being aimed at, women entrepreneurs consider unity of command as their weak asset (4.09). It is hard to assert authority, probably because of the problem on remuneration (4.12). With less authority, there is also a problem on discipline and diligence of the personnel and the respect for one's limitations (4.15). Results have shown that one can attain unity in management but if authority is not well in place, people seem to lose coordination and find difficulty in working with 
the others for the common good. More so if these people are not properly remunerated, that chain of authority seems also undermined.

Controlling. The establishment of control process is basic according to the women entrepreneurs (4.22). Importance is given to the establishment of management information system (4.21) that will monitor and assess the products and services so that feedbacks can be given to the management. Again, similar to directing, the problem is exercise of authority (4.09) to be able to evaluate the products. Mean rating was 4.14, categorically an effective rating. From the noncommercial group, the women entrepreneurs first and foremost look at the establishment of control process as a priority concern (4.09) and making changes in the system to be able to cope up with the standard (4.04). The lowest rating (3.76) was exercising authority over someone or a group. Women under the commercial group consider the need for management information system as a priority concern in controlling and the exercise of authority over someone or a group, both of which were rated with 4.41. Their lowest rating (4.17) was in making changes in the system to meet the standard. The differing perceptions of the two groups of respondents seem to indicate that woman entrepreneurs who belong to the commercial group are assertive of their authority and that monitoring, verifying and checking against the standard or in short quality control is more given attention. This can be explained by the nature of the enterprise the women have which is already under the commercial level.

Decision-making. Women are ready for alternatives (4.15) in decision-making. They consider the alternatives that will be beneficial to all (4.11) and they see to it that such alternatives are appropriate for the given environment (4.10). They may be weak in implementing the best solution or course of action (4.05) The noncommercial group establishes criteria first for appraising alternatives (3.96) before developing alternative solutions (3.95). They see to it that they have a grasp of the environment (3.93). On the other hand, the commercial group specific first the decision objectives (4.39) and diagnose the decision problem or situation (4.38) before developing alternative solutions. The perceptions of the two groups of woman entrepreneurs clearly indicate the cautiousness of the women from the commercial group. They see to it that what they are doing are aligned to their objectives and criteria established before they can decide on the more appropriate alternative course of action. Among the five management parameters considered for the women entrepreneurs, directing had the highest rating (4.17), followed by controlling (4.14) and third, business planning. (4.12). The lowest rating (3.85) was organizing. The women from the non-commercial group considered directing (4.01) as their most effective management aspect while the commercial group gave more particular attention on controlling (4.35). Both groups however, indicated that they are rated lower in organizing. The trend of results suggest that because of the nature of the enterprises of the women from the commercial group, they were more concerned of controlling the operations to assure them that their products or services are in the right track They are guided by the monitoring system that they have installed so that they will not be left behind with the ever changing demands of the environment.

\section{Risk Management Qualities Of Women Entrepreneurs}

Self-confidence $(19.63 \%)$ is the main asset of women entrepreneurs, followed by, their being proactive $(15.89 \%)$ to be able to make wise decisions (14.49\%). They however, considered themselves weaker in being holistic (4.21\%) and positive thinking (10.28\%).

From the non-commercial work, women consider self-confidence as their main asset (25.71\%) followed by their being 
proactive $(15.24 \%)$. On the other hand, women entrepreneurs from the commercial group are proactive $(16.51 \%)$ and decide questions wisely $(16.51 \%)$.

Women entrepreneurs under the commercial group anticipate more the future. They do not look at the day's earning only, but think of the succeeding days ahead for their continued operation. They have to make appropriate decision not only for a day but how it will be useful in the following days.

\section{Qualities of Women Entrepreneurs on Financial Management}

Women entrepreneurs practice fairness (26.17\%) and they think and act according to the given condition $(22.90 \%)$. Their decision therefore is best under a given situation (13.55\%). Only $4.67 \%$ indicated that they are analytical.

From the non commercial group of women, they also maintain fairness in their enterprise $(26.67 \%)$ and make decision too under a given situation (22.38\%). Only $2.38 \%$ signified that they are analytical. From the commercial group of women entrepreneurs, $6.88 \%$ said that they are analytical and can manage change.

Both groups of women entrepreneurs noted that majority are quite weak in analyzing situations and end results. This could be because of their complacency on the given condition of their enterprise. They are confident that their people will help them attain their goal and that their operation will continue given the resources they have.

\section{Women Entrepreneurs on Human Resource Management}

Leadership responsibility $(30.70 \%)$ is the topmost quality of women entrepreneurs. Their communication skill (17.21\%) ranks second, and their, their drive or motivation $(12.33 \%)$ to work.

The women from the non-commercial group also said they have leadership responsibility as their primary characteristic trait on human resource management $(33.81 \%)$ plus their ability to communicate (19.05\%). Similarly, the commercial group of women entrepreneurs consider their leadership responsibility $(27.730$ as their primary human resource trait and $15.95 \%$ indicated that they are motivated.

The data have shown that the women entrepreneurs look at their people as if they are her family members. They need to show leadership to make them move and as women they feel responsible for whatever happens to their people.

\section{Qualities of Women Entrepreneurs on Marketing Management}

Communication skills $(26.40 \%)$ is the primary asset of women entrepreneurs in marketing management followed by their ability to deal with people $(16.59 \%)$ and in managing conflict (15.89\%).

From the non-commercial group, women entrepreneurs also look at their communication skill $(28.10 \%)$ as their trait in marketing management followed by conflict management (19.05\%) and dealing with people (18.10\%). The commercial group of women entrepreneurs are also communicative $(24.77 \%)$ and they know how to deal with people (15.14\%).

Findings showed that women are powerful in marketing management because they can communicate well and it is easier for them to deal with people and offer their products or services. They are also trouble shooters and can moderate conflict situations. These traits are basically the traits of a mother as they talk to their children in thei most appropriate way without creating any harm or misunderstanding.

\footnotetext{
Qualities of Women Entrepreneurs on Production Management

Women entrepreneurs are efficient (38.55\%) and evaluative $(21.26 \%)$ in production management. Their weakest link $(12.38 \%)$ is being analytical.
} 
Women from the non-commercial group said they are efficient (36.67\%), evaluative $(18.35 \%)$ and analytical (14.75\%). The commercial group had similar perceptions on being efficient (40.37\%) and evaluative (18.35\%) and in addition, they accepted that they have the ability to think critically (16.51\%).

On production management, women are noted to be more efficient. This could be because what they are doing in their businesses is an extension of the business they have in running the family affairs. Women handle and manage the money including the establishment of good family relations. Men support their wives in maintaining the close family ties. They exercise authority for the implementation of policies and it is still the mother which monitors every activity in the family.

The study has shown that women entrepreneurs are efficient and motivated in running and managing their enterprises. They are proactive indicating that they always look at the business as something that will last and pass the test of the unstable environment around them. They may be aggressive but they find it quite difficult to exercise their authority in dealing with people. These traits could be trace from the nature of being a mother in a family. The mother is responsible for the good family relations plus the management of the financial resources in order that this will last for the needs of the family.

\section{CONCLUSIONS}

With all the measured management skills of women entrepreneurs' Risk and Financial aspects show significant relationships with effectiveness in Planning and Controlling. This implies that the skills in managing both the risk and financial aspects in business are highly influenced by women's planning and controlling ability. This finding further implies that the success of respective businesses of women entrepreneurs can be attributed from their ability to plan and manage ahead the risk and financial problems that might be encountered during the blast of their business activities.

Based on ANOVA result, the computed F-value of 4.647 is less than its corresponding critical values of 15.977 at $1 \%$ level of significance and 6.388 at $5 \%$. The test is not significant, thus there is no significant difference in the level of effectiveness of women entrepreneurs among the different aspects of management. Result suggest that women entrepreneurs' poses the same level of effectiveness in all the five areas of management such as planning, organizing, directing, controlling and decision making.

For column means, the computed F-value of 44.037 is greater than its corresponding critical F-values of 21.198 and 7.709 at $1 \%$ and $5 \%$ levels of significance respectively. The test is highly significant, thus there is a significant difference in the level of effectiveness of entrepreneurs between the two business areas. With a higher mean of 4.24, women entrepreneurs in noncommercial area can really be considered to be more effective entrepreneurs compared with those located at commercial area.

Difference in the effectiveness of women entrepreneurs from the two business areas can be attributed from being enthusiastic and innovative of those in the non-commercial area to compete with the large business located in commercial places. Entrepreneurs in a commercial area already felt confident that their respective business will somehow survive in the tight competitions in the industry, thus making them less concerned and effective in terms of the different management aspects of business.

\section{REFERENCES}

Harnois Catherine E. Feminist Measures in Survey Research, London: SAGE, 2013

Sirug, Winston, Basic Quantitative Methods for Business (An Introduction to 
Operations Research/Management Services).

Manila: Mindshapers Co., Inc. 2012

Carmichael, Jan, Leadership and Management Development,

New York: Oxford University Press, 2011.

Crawford, Mary, Transformation; Women, Gender, and Psychology, 2nd ed., New York: McGraw - Hill, 2012.

Halten, Timothy S., Principles of Small Business Management, 5th ed., Singapore: CENGAGE Learning, 2012.

Yukl, Gary, Leadership in Organization, 7th ed., New Jersey: Prentice Han, 2010.
Newstrom, John W., Organizational Behavior, Human Behavior at Work, 13th ed., Singapore: McGraw - Hill, 2011.

Fang, Yongging, Fundamentals of Management Concepts and Principles, Singapore: McGraw - Hill, 2011.

Kumar, Arun and N. Meenakshi, Marketing Management, 2nd ed., New Delhi: Vikas Publishing House, 2011.

Stenenson, William J., Operations Management, 10th ed., Singapore: McGraw - Hill, 2010. 